\title{
Tragedy of Self-immolation: An Iranian Case Study in the Towns of Salas Babajani and Sarpol Zahab
}

\author{
Hossein Mirzaee $^{1}$, Atiyeh Kamyabi Gol ${ }^{2 *}$, Javad Yousofi Labani $^{3}$ \\ ${ }^{1}$ Department of Sociology, Faculty of Letters and Humanities, Ferdowsi University of Mashhad, Iran \\ ${ }^{2}$ Department of Linguistics, Faculty of Letters and Humanities, Ferdowsi University of Mashhad, Iran \\ ${ }^{3}$ Department of Sociology, Tabriz University, Iran
}

Copyright (C) 2015 by authors, all rights reserved. Authors agree that this article remains permanently open access under the terms of the Creative Commons Attribution License 4.0 International License

\begin{abstract}
Self-immolation, affected by various factors, is the most common way of committing suicide among Iranian women especially in the western areas of Iran. The present research addresses the phenomenon of self-immolation among women in the two towns of Salas babajani and Sarpol Zahab located in the Kermanshah province. We also shed light on the sociolinguistic features (such as cultural norms, cultural expectations, education, religion, etc.) of self-immolation attempt victims. The participants in the research were twenty women who were self-immolation survivors in urban and rural parts of the research area. Sampling is a purposive sampling and data collection continued until saturation point was reached. Data was collected through deep and semi-structured interviews. Results indicate that most respondents belonged to the rural population $(75 \%)$, were Hagh followers $(50 \%)$, and were housewives $(70 \%)$. Moreover, most participants had elementary level education $(50 \%)$, poor economic conditions $(50 \%)$, and were descendants of illiterate parents $(70 \%)$. The mean age of those who attempted self-immolation was 25 years old. In addition, the average age difference with their husband was 14 years. In terms of marital status, 30\% were married, 35\% were single, and $35 \%$ were divorced. Most of the married and divorced women $(46.15 \%)$, had no children, and had married without full consent. $80 \%$ of participants stated that they had a history of domestic violence, and $70 \%$ of respondents stated that they had a history of self-immolation in their relatives.
\end{abstract}

Keywords Self-immolation, Women, Sociolinguistics, Salas Babajani, Sarpol Zahab, Educational Background, Marriage

\section{Introduction}

Suicide, which results in death, is the act of deliberately hurting oneself [1]. In contrast, "the attempt to commit suicide" is a phrase which is used for all nonfatal actions in which the person damages themselves skillfully [2]. Suicide and suicide attempt could be viewed as complex social and psychological phenomena which are affected by personal and environmental factors [3]. Methods of committing suicide in different countries differ based on cultures, symbols, imitation and religion [4]. One of the painful suicide attempts is self-immolation which is more prevalent in Eastern societies as compared to the Western societies [5]. Based on the latest data from death registration system in Iran, 11 people die by suicide daily, from which 4 end their lives through self-immolation [6]. Unfortunately Emergency rooms and burn hospitals are faced with self-immolated women who in facing life issues and problems find no other solution except destroying themselves in the most heartbreaking way [7].

Self-immolation and, in general, all forms of suicide may have a religious background. The religious tradition "Sati" is directly related to the Hindu religion. Buddha's followers use fire for protesting. In religious sources of Jews and Christians fire is a purifier. However, fire is mentioned as the severest punishment in The Holy Quran [8]. Self-immolation can be divided into two main categories based on the reasons behind the attempts: 1. Political Self-immolation in which individuals use self-immolation as a kind of protest to get the officials' attention and fight for their beliefs. Many cases of this type have been reported among Indians, Arabs, Bulgarians, and Tibetans ([31], [30], [32], [29]) 2. Non-political Self-immolation takes place for a variety of non political reasons such as social, economical, or cultural matters. In Iran, we generally witness Non-political Self-immolation.

Self-immolation in Kermanshah province from over the age of 5 corresponds to about $64.2 \%$ of patients admitted to burn units. This occupancy rate is among the highest percentages of beds occupied by patients with self-inflicted burns throughout the world [9]. Since Kermanshah province has a lot of self-immolation amongst women, the present study investigates the influence of some variables (such as 
age, marital status, imitation, marriage, education, history of family violence, occupation, religion, number of children among married and divorced women, economic status, place of residence) on self-immolation among women in this area.

\section{Materials and Methods}

Due to the nature of the subject, a qualitative method (oriented construction) was used in the present research. The research population consisted of all women who had committed self-immolation and were rescued in both rural and urban areas of Sarpolzohab and Salas Babajani (Kermanshah Province) cities in the last 7 years (2008-2015). Identifying and accessing them was done through introduction made by some of their friends and some clinics. To determine the sample size, theoretical sampling was used- samples which theoretically have the most benefit and are cornerstones of theory development. Due to some limitations such as people's unwillingness to be interviewed or lack of suitable physical and mental condition for an interview, we used the purposive sampling. The interview process continued until data saturation was reached which happened at 20 interviews. The data in this study was collected through a combination of in-depth and semi-structured interviews using note-taking, recording, and transcribing key points. Since suicide is considered a sin in Islam and is generally frowned upon by Iranians, individuals who commit suicide attempts are not inclined to share their stories with others. In fact, many families who have self- immolation victim members avoid talking about the matter at all costs. Therefore, the data collection was a difficult and timely procedure since the researchers had to gain each victim's trust before attempting to conduct interviews. Let us now look at the results.

Most of participants $(70 \%)$ had illiterate parents. As for their type of marriage, both among married and divorced women, it was deduced that about $(77 \%)$ of them were married without their consent. As interviewee number 5 asserts:

"From childhood I understood that I was chosen for my cousin who was 12 years older than me. I told myself until I grow up my cousin will marry and continue his own life _I used to cheer myself because I couldn't imagine him as my husband at all. Years passed and I spent my primary and guidance school in my village and with a lot of adversity and the mediation of my uncle I could persuade my parents to go to high school in the city. One day, not long after school, my uncle came to our home to ask for my hand in marriage for his son. I couldn't believe it. It was a very hard situation; I wanted to shout and say that I don't want to marry him, but I was afraid and didn't say anything. I have never shouted at my family and I waited for my father to suggest that it was too soon. But he didn't say anything and they appointed the time of engagement themselves; not even considering that it is me who has to get married and not them. Finally, the engagement day arrived and I couldn't say anything during that time and only cried; I didn't go to school, either. We got engaged and a month later got married. I told myself at least I may fall in love after marriage and be able to make my life like most of the girls who lived nearby and had gotten married by force. After some weeks I understood that the condition is harder than what I was forecasting; I could only cry. I felt that my life had ended; I couldn't even feel for seconds that I was fortunate. I didn't have any way back. Sometimes I thought of divorce, but when I looked at my family and was assured that they would never agree, I didn't take any action. Life wasn't enjoyable any more until one morning when there wasn't anybody at home I picked up the oil pot and pour oil on myself and burned myself".

From the point of having children among married and divorced women, most of them (46.15\%) did not have any children, $38.46 \%$ had one or two children and only $15.38 \%$ had three or more children. According to the age of marriage among married and divorced women, the average age of marriage was 18 , the lowest age was 14 and the highest was 22 years. With regards to the significant low average age of marriage among these participants, it can be added that people at this age have a lower competence regarding marriage and marital ties and are not yet ready to start a new life and so marriage cannot act as a dissuasive factor in committing self-immolation.

Based on table 2 which elaborates on the reasons behind women self-immolation, effective factors among single women included rigidity of families $(20 \%)$ and monotony of life (15\%); and among the married participants included economic problems (15\%), physical violence $(10 \%)$ and legal inability to get a divorce (5\%). In this regard, interviewee 19 stated:

"Six months had passed from my marriage with my cousin whom I was forced to marry. In the first month our relationship was not bad and had little disagreements with each other and I always tried to be quiet and quit fighting, but as the time passed our economic problems became more aggressive and my husband became more violent and lost his temper at the smallest things and used to start fighting. He beat me many times; sometimes I just couldn't handle it and just left and went to my parents' home, but my family became worried, blamed me and said that my husband is right and I was forced to go back home. When my husband understood that my family did not support me, he became more violent and beat me. Life became intolerable for me because I ended up getting a full beating on the simplest matters. One day when I was sitting with the neighbors, my husband returned home and called me in. I was still talking to neighbors and went home a bit late. My husband came out of house and started abusing and beating me. I was belittled in front of the neighbors and when I arrived home I set myself ablaze, but as luck would have it, I stayed alive. My husband and neighbors put out the fire and after being hospitalized for some days, I was alive and returned home. 
Three years have passed from that moment and I have a child and try to cope with my fortune because of my child. The only thing that gives me hope is to try to make the best for my daughter so as not to let her have the same fortune as her mother".

The divorced women emphasized on the negative view of people toward them and having no hope for a better life in the future $(20 \%)$ and no economic and emotional support after getting divorced. Interviewee 3 told us her life story:

"Three years had passed from my divorce. My husband was an addict. I tried to help him quit and save my life but I couldn't and at last I decided to get a divorce. It was not long after the divorce that I realized just how bad the situation was. Everybody looked at me in a way as if I was guilty although he was the one who was addicted, but they said that I should have tolerated the situation and continued. After some weeks I had a suitor who was 28 years older than me. I told myself he is certainly crazy for even thinking of proposing to me and I rejected his marriage proposal, but the next suitor was 25 years older than me, as well. I soon realized that I was the crazy one for thinking any single boy my age would want to marry me now that I was divorced. I found I either had to marry someone 20 or
30 years older than me or stay single to the end of my life. I was tired of the situation and people's constant nagging words that "if you were a suitable wife you wouldn't be divorced" which bothered me till the end of my life. There was no other way for me. My family mocked me most of the time and I was ashamed to get money from them to charge my cell phone. I always wanted to be economically independent, but I didn't have any ability and profession; my family didn't support me economically, either. I had reached a dead-end in my life and had no hope for a better future. I was sure that it is my fate and there is no way for a change; I couldn't yield to marry someone who is 30 years older than me. There was no way except suicide. So, one day I decided and pour some oil on myself and lit the match, but as I was unfortunate my brother arrived in time and put the fire out. I was in the hospital for some days, then I returned home and the conditions became even worse than before. It was not only accused of the crime of divorce, but the crime of suicide was added to it and I was a culprit who was sentenced to death. After some days I decided to kill myself, but when I remembered my mother who told me if you kill yourself I will do it too, I changed my mind. I tried to continue and suffer more until the end of my life."

Table 1. Demographic and background characteristics of the participants

\begin{tabular}{|c|c|c|c|c|}
\hline Religious Status & Employment Status & Residential Status & Marital Status & The Economic Situation \\
\hline $\begin{array}{l}\text { Hagh Followers } 50 \% \\
\text { Suni } 30 \% \\
\text { Shia } 20 \% \\
\end{array}$ & $\begin{array}{c}\text { Housewife } 70 \% \\
\text { Freelance } 20 \% \\
\text { Students } 10 \% \\
\end{array}$ & $\begin{array}{r}\text { Urban } 25 \% \\
\text { Rural } 75 \%\end{array}$ & $\begin{array}{c}\text { Married 30\% } \\
\text { Single 35\% } \\
\text { Divorced 35\% } \\
\end{array}$ & $\begin{array}{c}\text { Poor } 50 \% \\
\text { Average } 35 \% \\
\text { Good } 15 \% \\
\end{array}$ \\
\hline Parents' Educational Background & \multicolumn{2}{|c|}{$\begin{array}{l}\text { Type of Marriage among Married and Divorced } \\
\text { Participants }\end{array}$} & $\begin{array}{c}\text { Age of Participants at the } \\
\text { Time of the } \\
\text { Self-immolation } \\
\text { Attempts }\end{array}$ & $\begin{array}{l}\text { Participants' Academic } \\
\text { Background }\end{array}$ \\
\hline $\begin{array}{c}\text { Illiterate } 70 \% \\
\text { high-School diploma 25\% } \\
\text { Higher than High-school diploma } \\
5 \%\end{array}$ & \multicolumn{2}{|c|}{$\begin{array}{c}\text { With Individual's consent } 23.7 \% \\
\text { Traditional or Imposed Marriages } 76.92 \%\end{array}$} & $\begin{array}{l}\text { Average } 25 \text { years } \\
\text { Youngest } 17 \text { years } \\
\text { Oldest } 40 \text { years. } \\
17-30 \text { age group }(85 \%)\end{array}$ & $\begin{array}{c}\text { Elementary } 50 \% \\
\text { Guidance school } 20 \% \\
\text { High school } 20 \% \\
\text { University Student } 10 \% \\
\end{array}$ \\
\hline Couple's Age Difference & $\begin{array}{c}\text { History of Domestic } \\
\text { Violence }\end{array}$ & $\begin{array}{c}\text { History of } \\
\text { Self-immolation }\end{array}$ & Marriage Age & Number of Children \\
\hline Average 14 years & $\begin{array}{l}80 \% \text { claim they have a } \\
\text { history of domestic } \\
\text { violence }\end{array}$ & $\begin{array}{l}70 \% \text { claim their } \\
\text { relatives had a history of } \\
\text { self-immolation }\end{array}$ & $\begin{array}{l}\text { Average } 18 \text { years } \\
\text { Youngest } 14 \\
\text { Oldest } 22 \\
\end{array}$ & $\begin{array}{c}\text { Childless } 46.15 \% \\
1 \text { to } 2 \text { children } 38.46 \% \\
3 \text { or more children } 15.38 \% \\
\end{array}$ \\
\hline
\end{tabular}

Table 2. Reasons for self-immolation

\begin{tabular}{|c|c|c|}
\hline Singles & Divorced & Married \\
\hline Family added pressures $20 \%$ & $\begin{array}{c}\text { Lack of financial and emotional support after divorce } \\
10 \%\end{array}$ & Economic problems (15\%) \\
\hline Monotonous lifestyle $15 \%$ & $\begin{array}{c}\text { Negative outlook of people and lack of hope for a } \\
\text { better life in the future } 20 \%\end{array}$ & Physical violence and abuse $10 \%$ \\
\hline & & Inability to get a divorce $5 \%$ \\
\hline
\end{tabular}




\section{Discussion}

According to the findings, most of the attempters were single or divorced. This result is in contrast to the previous researches, including [9], [10] and [11]. The high number of the divorced women who committed self-immolation can be the due to the traditional style of thinking customary to the people of the studied region which puts a great deal of pressure on the women who get a divorce. In fact the divorced women shy away from society and the possibility of another marriage is close to none and so this leads women to self-immolation.

Most of the victims of this study were villagers who lived in rural areas which was consistent with previous studies such as [9], [12] and [13]. Most of the villages in this study are situated in the in the mountainous areas and have no fertile lands to farm on and have no other source of income; therefore, from an economic point of view, the participants are mainly poor. Also, having almost impassable roads, low economic status, low travels or commutes to the urban areas and the rigid traditional beliefs of the inhabitants have a strong influence on the life of rural areas and their ill-treatment of women create pressure and limitation for women which finally result in commiting risky behavior on the part of the women to escape from constraints.

Most of the participants in studies such as [9], [14], [15], and [16] were home owners. Having economic independence can give freedom and more self-confidence and also give more freedom of choice to one's lifestyle. Therefore, lack of financial security leads to dependence on others and less self-esteem and also less power to change one's life and situation. Being housewives, lacking sufficient entertainment activities and not enjoying life on the whole, were among factors which caused confusion, depression, imbalance between personal and family life, and an outbreak in high-risk behaviors for the participants of the present study.

In this research, most participants and their parents were either illiterate or had minimal education and this was in accordance with [15], [9], [14], [17] and [18]. Unfortunately, due to poor educational conditions and shortage of girly high schools in rural areas and with regards to low economic status and commuting problems to the city for girls and some untrue beliefs about girls' education in other cities and despite the fact that if they attained good grades in the university entrance exam they would not be able to travel to other cities and continue their education all give way to the low educational status of the women of this area. In addition, poor educational conditions, poor economy and lack of right cultural beliefs about girl's education tend to result in the low educational status among the women of this area and these factors have yielded to women's lack of employment and in turn lack of economic independence. Low educational status as a result of having no employment or economic independence has disabled the studied participants in this study. The participants had difficulty dealing with the issues and problems of life and in most cases, when having to deal with life issues; they were stricken with fear, stressed out and depressed. Their way out seemed to be committing risky behavior such as self-immolation to get rid of the deadlocks created for them. Most of the participants in this study had a low educational status that was in accordance with [14] and [10]. Economic wellbeing is of the highest priorities in the present Iran and not having a good economic status takes away an individual's choice of a preferred lifestyle and weakens $\mathrm{him} /$ her against life problems. Therefore, women's poor economic status can be a powerful factor which can lead them self-immolation.

Findings related to the average age of the people who committed self-immolation are in accordance with studies such as [9], [11], [20], and [21]. Based on this, we can say that committing self-immolation is more common among the young and teenagers. This behavior can be affected by the critical aspects of teenager's life such as independence, irritability, excitement and responsiveness. Therefore, by training these youngsters, their parents and their relatives about the age requirements of this period and how to manage faced problems, the number of self- immolation cases can be greatly decreased [9].

In this research $70 \%$ of participants claimed that their relatives had self-immolation background that is in accordance with [9]. This problem can be an affirmation on Ahmadi's (2006) theory which believes self-immolation may have a repetitive pattern. This type of suicide may be consistent among the women of our society and transcend from one generation to another as a viscous circle. In their lifetime, these women learn unconsciously, through only hearing life stories of people who have chosen suicide as a solution to their problems; in fact, most participants had not seen the repercussions of those decisions and so in the time of psychological pressures, cognitive forces and perceptual contractions they immediately resort to self-immolation as a way out or solution.

In this study, a significant $80 \%$ of the sample said they had experienced physical violence in the family which was consistent with [22], [23], [24] and [25]. Based on the analytical psycho-socio analyses, violence against women can be associated with suicidal thoughts and harming the spouse. Freud believed that when a person does not respond to aggression and violence and anger and represses this anger, they may form a pattern of abuse which can lead to suicide [26]. Research has shown that lack of self worth and humiliation caused by violence, can lead to severe depression, anxiety, fear, and eventually suicide in women [27]. Therefore, given the history of violence in most participants' lives in this study, domestic violence can deeply affect women and push them to the brink of death; therefore, it only seems logical that we should provide appropriate educational programs for families to try to reduce these problems. Out of the participants, $77 \%$ were married and divorced individuals who had attempted self-immolation and were forced into matrimony. Forced marriage is a risk factor in women's self-immolation. Since 
this type of marriage is more likely to be imposed on girls and they tend to be more emotionally charged than boys, it only seems fair that families ask for the girls' opinions and preferences at the time of marriage.

One main problem which was reflected in the results, was the lower than normal age of marriage among the participants. The mean age for marriage was 18 years among participants which is significantly lower than the mean age of marriage in the Iranian society. Because of cultural taboos in our society, and especially in the region being studied, a great deal of essential information about marriage is kept from couples and especially girls. This lack of awareness and knowledge, low age of marriage for girls and their being forced to marry unfavorable spouses all provide a basis for psychological damage.

In this study, cases of self-immolation among Hagh followers were relatively higher than Shiite and Sunni followers. Some possible reasons behind this finding could be the lower economic situation of these followers and also the absence of religious warnings and prohibitions in their religion. Hagh followers are an Iranian minority sect that came into being in the seventh century. They mainly reside in the Kurdish Western part of Iran. Hagh followers are a secret society and they do not easily disclose information about their beliefs [33]. According to [34] "the group's spiritual training, psychic experiences and their inner intuitions carry on within a limited circle of the group and thus have its own particular discourses". Islam has directly constituted suicide as a deadly sin in verse 29 of Nisa Surah and by doing so has succeeded in the reduction of suicide attempts among its followers [28].

In this study the majority of married and divorced participants and had no children or had one or two children. The researchers hypothesized that with the increase in the number of children decreases the chances of self-immolation. One reason behind this could be because of stronger family ties and family obligation and parental responsibility towards their children.

In the present study, the mean age difference between spouses is higher than normal. Generally, the age difference between spouses' benefits men and rather harms women. In Iran today, due to the rapid cultural changes, age difference can yield to disastrous outcomes such as vulnerability in women; this problem is only heightened when we regard deprived areas such as the city such as DTP and Salas Babajani and Sarpolzohabtowns. In fact, other variables such as incorrect cultural norms about women, women's low education level, lack of employment and financial independence, can be extremely dangerous and can set the scene for irrational and risky behavior such as self-immolation. That is why married women in the present study regarded bad economic status, physical violence and inability to get a divorce as influential factors for self-immolation. As for the divorced women in the study, they considered lack of financial and emotional support from families after divorce, negative views of society and lack of hope for a better future as the most important factors. Single participants referred to family rigidity and monotonous lifestyle as the main contributors to self-immolation. These factors have also been mentioned by previous studies [9].

\section{Conclusions}

This study demonstrates that self-immolation is among the most important social, cultural and psychological problems in the Iranian society and is a complex phenomenon that has many different causes. The results revealed two influential factors- namely marriage and women's education- not only have a direct impact, but also an indirect impact on self-immolation. Providing the necessary premarital information to parents and giving girls' the opportunity to choose their own spouses can help to prevent girls' disastrous outbursts such as self-immolation. When one chooses their spouse, they tend to have more patience in dealing with life problems and obstacles and can focus more on building their own lives. By choosing their own spouses, couples tend to select those with more common grounds and in turn would have fewer arguments which could push them to the brink of death by suicide.

Another aspect of the issue is divorce and the society's outlook towards those who are divorced. For example, in the present study, it was determined that the main problem was not the general concept of divorce, but the society's perspective towards those who had been divorced which pushed the participants to self-immolation. This study also found that Women's education has a key role in suicide prevention. Higher level education and awareness, recognition, financial independence, confidence and the ability to choose one's lifestyle could play a vital role in reducing the social abnormalities such as suicide and self-immolation.

All in all, according to the findings of this study, promoting public cultural paradigms and awareness raising for parents and teenagers, stopping forced marriages, paying closer attention to age differences between spouses, publicizing the importance of education for girls and boys with regards to reaching financial independence and in turn providing the necessary ability to deal with everyday life obstacles, providing recreational facilities for women's leisure time, can be important factors which can come to the aid of society regarding self-immolation prevention.

\section{Acknowledgements}

The authors would like to express their deep gratitude to the participants of the study for their patience and trust in the researchers. We would also like thank all those who supported us during the study. 


\section{REFERENCES}

[1] Amos T, Appleby L. Suicide and deliberate self-harm. In Appleby L., Forshaw D.M., Amos T., Barker H. Postgraduate psychiatry: clinical and scientific foundations, 347-357. London: Arnold, 2001.

[2] Rezaeian M. et al., Recognition of some of the risk factors for suicide and attempted suicide within Ilam province and their direction of function. Journl of Health System Res. 6(1), 86-94. 2010.

[3] Mann J.J, Waternaux C, Haas G.L, Malone KM. Toward a clinical model of suicidal behavior in psychiatric patients. Am Journal of Psychiatry, 156, 181-189. 1999.

[4] Grossoehme D.H, Springer L.S. Images of God used by self-injurious burn patients. Burns, 25(5), 8-443, 1999.

[5] Sheth H. Dziewalski P. SettelYAD. Self-inflicted burn: A common way of suicide in the Asia population a 10-year retrospective study. Burns, 20(4), 5-334, 1994.

[6] Naghavi M. Mortality profile in 18 provinces of Iran, Tehran: Iranian Ministry of Health and Medical Education, Deputy of Health (in Persian). 2001.

[7] Lotfi M. Review of Self-Inflicted burn Female patients of admitted in ward in one of Treatment Educating center of Tabriz, Research Paper, University of Medical sciences, Tabriz, Iran. 2000.

[8] Ahmadi et al., A., Epidemiology of successful suicide cases admitted in the hospital. Kermanshah University of Medical Sciences, Section of Mental Health Letter, 29 and 30, 23-35. 2006.

[9] Yousefi lebani J. Mirzaei H. The study of Factors Affecting of Self-Burning among Woman (The Case Study of Javanrood and Ravansar cities). Journal of Health System 9(7), 672-681. 2013

[10] Qalambor A. et al., examining the social and demographic characteristics as risk factors for suicide, The Medical Journal, 4, 246-233. 2010.

[11] Laloe V, Ganesan M. Self-immolation a common suicidal behavior in eastern Sri Lanka. Burns. 28(5), 475-80. 2002.

[12] Ahmadi, A., The prevalence of suicide in suicide attempters in the city of Islamabad West, Journal improvement, 1, 36-26. 2005.

[13] Mousavi F., Shah Mohammadi D, Kafashi A, Epidemiologic study of suicide in rural areas, Journal of Clinical Psychiatry and Psychology (thought and behavior), 5. 4-10 (in Persian). 2000

[14] Chaby F. Allah, E. Women's status in his burnt. Quarterly Faculty of Health Sciences Research, 4, 73-65. 2011.

[15] Memari et al. A, Causes Attempt to suicide at Married Woman. Journals. 12 (1), 47-53. 2006.

[16] Feeli. A. A Demographic investigation into Self-burning among the women Bedridden in Shiraz Qutbaddin Hospital During1999 -2004. Journal of science paek Noor. 1, 56- 68. 2004.
[17] Sakhare S. Analytical study of 1200 suspicious deaths of newly married women in Vidharbha region of Maharashtra state in India. In: Proceedings of the Womens' Decade World Conference, Nairobi, Kenya, 1985.

[18] Kumar V. Burnt wives: a study of suicides. Burns; 29(1), 5-31. 2003.

[19] Barhkordar et al. N. An investigation into suicide process and the effective factors on in rural areas of Kermanshah city during 1379-1385. The medical journal 27(4), 219- 225. 2009.

[20] Sukhai A, Harris C, Moorad R.G, Dada M.A. Suicide by self-immolation in Durban, South Africa: A five-year prospective review. Am J Forensic Med Pathol; 23(3), 8-295. 2002.

[21] Shkrum M.J, Johnston K.A. Fire and suicide: A three-year study of self-immolation deaths. Journal of Forensic Science; 37(1), 208-21. 1992.

[22] Khosravi Z, Khaghani fard M, Relationship with spouse abuse and suicidal thoughts tend to harm his wife in Tehran women, Journal of Women's Studies, 6, 99-113. 2004.

[23] Kaslow, J.et al. Factors that mediate and moderate the Link between partner abuse and suicidal behavior in African-American women. Journal of Consulting and Clinical Psychology 66(3), 533-540. 1998.

[24] Golding, J. M. Intimate partner violence as a risk factor for mental disorders: A Meta-Analysis. Journal of Family Violence 14(2). 1999.

[25] Hicks MH, Bhugra D. Perceived causes of suicide attempts by U.K South Asian women. Am Journal of Orthopsychiatry.; 73 (4), 455-62. 2003.

[26] Kaplan H, Haroold B. psychiatry abstract, Translated by Poor Afkari N .Tehran. Zoghi Publication. 2000.

[27] Hampton, Robert, Jenkins P., Vander. A. Physical and Sexual Violence in Marriage. Family Violence. London \& Inc. 1999.

[28] Baasher, T.A. Islam and mental health. Eastern Mediterranean Region Health Services Journal, 7, 372-376. 2001

[29] LaFraniere, S. More Monks Die by Fire in Protest of Beijing, New York Times, January 9, 2012.

[30] Bakri, N. Self-Immolation Is on the Rise in the Arab World, New York Times, January 20, 2012.

[31] Coleman, L. The Copycat Effect: How the Media and Popular Culture Trigger the Mayhem in Tomorrow's Headlines. New York: Paraview Pocket-Simon and Schuster. p. 66. ISBN 0-7434-8223-9. 2004.

[32] Toshkov, V. Bulgaria experiencing spate of self-immolations. AP/Yahoo news. Retrieved 1 April 2013.

[33] Khodabande, A. Knowing Ahle Hagh Sect. Tehran: Amirkabir, 2003.

[34] Farrokhnia, R. Reza, R. Belief system of Sahneh ahl-e-haq sect of Iran. Anthropologist, 12(2), 87-93. 2010. 